\title{
IMPLEMENTASI JIWA WIRAUSAHA DAN PEMANFAATAN MEDIA SOSIAL TERHADAP MINAT BERWIRAUSAHA PADA MAHASISWI PURWAKARTA
}

Oleh :

Ade Nurhayati Kusumadewi

Program Studi Manajemen - STIE Dr. Khez Muttaqien Purwakarta

adenurhayatikd@gmail.com

Hikmah Nur Fitriani

\begin{tabular}{|c|c|}
\hline Article Info & Abstract \\
\hline $\begin{array}{l}\text { Article History: } \\
\text { Received } 25 \text { July }-2020 \\
\text { Accepted } 20 \text { August }-2020 \\
\text { Available Online } \\
\text { O7 Sept - } 2020\end{array}$ & $\begin{array}{l}\text { The research with the title of the influence of entrepreneurial spirit and } \\
\text { the use of social media on the interest of entrepreneurship in female } \\
\text { (case study on STIE Dr. Khez. Muttaqien and STIEB Perdana Mandiri } \\
\text { in Purwakarta). The purpose of this study was to determine the effect of } \\
\text { entrepreneurial spirit and the use of social media on the interest of } \\
\text { entrepreneurship in private college students in Purwakarta. The } \\
\text { respondent in this study were private college students in the Purwakarta } \\
\text { economic cluster. The number of respondents in this study was } \\
\text { determined by } 95 \text { respondents using a sampling technique called } \\
\text { probability sampling technique. The research method used is descriptive } \\
\text { method is a method that is carried out by collecting, presenting and } \\
\text { analyzing data so as to provide a fairly clear picture of the object under } \\
\text { study. This study uses a multiple linear regression analysis model with } \\
\text { the help of IBM SPSS version } 22 \text {. The results of this study shows that the } \\
\text { variable entrepreneurial spirit and the use of social media have a } \\
\text { positive and significant effect on the interest in entrepreneurship in } \\
\text { female private university students in Purwakarta. }\end{array}$ \\
\hline $\begin{array}{l}\text { Keyword: } \\
\text { Entrepreneurial Skills, } \\
\text { Utilization of Social } \\
\text { Media, Interest in } \\
\text { Entrepreneurship }\end{array}$ & \\
\hline
\end{tabular}

\section{PENDAHULUAN}

Saat ini, dunia entrepreneur tidak hanya didominasi oleh kaum lelaki tetapi sejak adanya emansipasi wanita, kaum wanita juga telah mengambil bagian ini. Perempuan bekerja saat inipun telah banyak kita temui, posisi jabatannya beragam. Tetapi sebagai wanita akan lebih tertarik untuk bekerja dengan pengaturan waktu yang lebih fleksibel dikarenakan untuk wanita yang sudah berkeluarga hal ini sebagai bahan pertimbangan untuk tetap dapat mengurus keluarga. Lebih lanjut lagi, Allah SWT menggariskan bahwa seorang Muslim harus berusaha menemukan rezekinya, seperti yang dicontohkan oleh Siti Khadijah isteri Rasulullah SAW. Beliau merupakan suri teladan sempurna bagi seluruh perempuan di dunia. Satu hal menarik yang sering menjadi sorotan dari sosok Siti Khadijah, yaitu kenyataan bahwa ia adalah seorang business women sukses pertama di Arab pada masa itu dengan kekayaan melimpah ruah, serta perniagaan dimana-mana. Atas keberhasilannya ini, ia pun dijuluki "Ratu Quraisy" juga "Ratu Mekah". Namun kenyataan dilapangan bahwa tidak sedikit dari masyarakat saat ini khususnya wanita mereka lebih memilih bekerja di perusahaan baik negeri maupun swasta, paradigma masyarakat bahwa bekerja di perusahaan negeri maupun swasta lebih menjanjikan daripada mengambil keputusan untuk menjadi women preneur masih menjadi minoritas. Begitupun pandangan yang masih diemban oleh mayoritas para mahasiswi bahwa mereka lebih menginginkan menjadi pegawai atau karyawan pada suatu perusahaan baik negeri maupun swasta yang menurut mereka lebih terjamin. Berikut data jumlah mahasiswa yang bekerja : 
Tabel 1. Jumlah mahasiswa yang bekerja

\begin{tabular}{|c|c|c|c|}
\hline PTS & Bekerja & $\begin{array}{c}\text { Tidak } \\
\text { Bekerja }\end{array}$ & Jumlah \\
\hline STIE & $80 \%=$ & $20 \%=$ & 385 \\
Muttaqien & 308 & 77 & orang \\
& orang & orang & \\
\hline STIE & $40 \%=$ & $60 \%=$ & 1209 \\
Perdana & 484 & 725 & orang \\
Mandiri & orang & orang & \\
\hline
\end{tabular}

Sumber : Data Olahan Peneliti dari Data Perguruan Tinggi

Untuk mengurangi hal seperti itu dan merubah pola pikir mahasiswa, maka pihak perguruan tinggi mendorong mahasiswanya agar memiliki minat dalam berwirausaha. Merujuk pada Undang-Undang No.20 Tahun 2003, Perguruan Tinggi memegang peranan penting bagi pembangunan Sumber Daya Manusia Indonesia dan merupakan bagian integral dari sistem pendidikan nasional yang bertujuan untuk berkembangnya potensi peserta didik agar menjadi manusia yang beriman dan bertakwa kepada Tuhan Yang Maha Esa, berakhlak mulia, sehat, berilmu, cakap, kreatif, mandiri dan menjadi warga negara yang demokratis dan bertanggungjawab. Minat berwirausaha juga diduga dapat timbul melalui mata kuliah yang diajarkan. Salah satunya yaitu mata kuliah kewirausahaan yang diikuti dengan berbagai bentuk pelatihan atau praktek langsung dalam mengembangkan jiwa kewirausahaan mahasiswa. Pelatihan atau praktek langsung yang dilakukan untuk dapat menimbulkan minat berwirausaha pada mahasiswa antara lain : 1) Melakukan workshop kewirausahaan dengan target tersusunnya business plan. 2) Mengadakan seminar yang berkaitan dengan entrepreneur.

3) Melakukan promosi atau penjualan secara langsung terhadap suatu produk melalui eveneven yang diadakan oleh pihak kampus maupun dari pihak luar. Dengan mempersiapkan jiwa kewirausahaan maka nantinya akan timbul minat berwirausaha dalam diri mahasiswa tersebut.

Meningkatnya perkembangan dunia teknologi dalam beberapa tahun terakhir, menjadikan dunia internet menjadi alat komunikasi yang banyak diminati oleh masyarakat. Perkembangan inipun menjadi semakin pesat setelah internet mulai dapat diakses melalui telepon seluler dan muncul istilah telepon cerdas (smartphone). Jejaring sosial dunia maya ini berbasiskan web yang menyediakan beragam cara bagi pengguna untuk berinteraksi dengan komunitas dan banyak orang. Kecanggihan dari situs jejaring sosial tersebut memungkinkan setiap individu saling bertukar informasi kepada siapa saja melalui fasilitas yang disediakan, baik facebook, instagram ataupun yang lainnya. Salah satunya yaitu dapat dijadikan sarana kegiatan promosi, yang mana kegiatan promosi itu lebih efektif dan efisien karena rendahnya biaya yang meski dikeluarkan. Untuk itulah diharapkan agar semakin banyak tenaga kerja khususnya para tenaga kerja terdidik yang telah mempunyai pemikiran terdidik untuk berwirausaha. Terutama tenaga kerja terdidik wanita.

\section{KAJIAN PUSTAKA PEGEMBANGAN HIPOTESIS}

\section{Kewirausahaan}

Istilah kewirausahaan pertama kali diperkenalkan oleh Richard Cantillon (1755) dan pakar ekonomi J.B. Say (1803) yang kemudian diterjemahkan ulang oleh Hendro, M.M (2011:29) untuk menggambarkan para pengusaha yang mampu mengelola sumbersumber daya yang dipunyai secara ekonomis (efektif dan efisien) dari tingkat produktivitas yang rendah menjadi lebih tinggi.

Menurut Kasmir (2008:16) secara sederhana wirausahawan (entrepreneur) merupakan orang yang berjiwa berani mengambil risiko untuk membuka usaha dalam berbagai kesempatan. Berjiwa berani mengambil resiko artinya bermental mandiri dan berani memulai usaha, tanpa diliputi rasa takut cemas sekalipun dalam kondisi tidak pasti. Ungkapan di atas mengandung maksud bahwa seorang wirausaha adalah orang yang memiliki kemampuan untuk menciptakan sesuatu yang baru, berbeda dari yang lain dengan produk atau jasa yang sudah ada sebelumnya.

Kewirausahaan secara epistimologi adalah padanan kata yang diambil dari kata Entrepreneurship dalam bahasa Inggris, unternehmer dalam bahasa Jerman, ondernemen dalam bahasa Belanda, sedangkan bahasa yang digunakan di Indonesia adalah kewirausahaan. Kata entrepreneur sebenarnya berasal dari bahasa Prancis yaitu entreprede yang berarti petualang, pengambil resiko, pengusaha (orang yang mengusahakan suatu pekerjaan tertentu), dan pencipta dengan menjual hasil karya ciptaannya (Hendro, 2011:29).

Kewirausahaan menurut Anwar Muhammad (2014:08) berasal dari dua kata Wira artinya pahlawan, laki-laki, perwira dan usaha artinya perbuatan atau prakarsa, ihtiar daya upaya demi mencapai maksud yang diinginkan. 
Kewirausahaan menurut Daryanto (2012:02) adalah kemampuan kreatif dan inovatif yang dijadikan dasar, kiat dan sumber daya mencari peluang sebagai sumber mencapai tujuan sukses.

Kelebihan yang dilakukan oleh Perguruan Tinggi salah satunya adalah proses pembelajaran yang lebih menekankan pada mahasiswa sebagai objek dan subjek pembelajaran (student-centerd lerning) disamping kesiapan tenaga pengajar dan fasilitas pendidikan yang dimiliki Perguruan Tinggi. Konsep pendidikan juga perlu didesain untuk menumbuhkan semangat kewirausahaan dan peningkatan soft skills serta success skills, sehingga lulusan Perguruan Tinggi akan mempunyai karakter percaya diri yang tinggi, memiliki kearifan terhadap nilai-nilai sosial dan kultur bangsa, kemandirian serta jiwa kepemimpinan yang kuat (Dirjen Dikti, Depdiknas RI, 2004).

Merujuk pada tujuan pendidikan nasional dan visi Dirjen Dikti Depdiknas Republik Indonesia tersebut secara tersirat dapat disimpulkan bahwa pendidikan tinggi bukan semata bertujuan untuk mendidik Sumber Daya Manusia yang memiliki kemampuan dalam bekerja di berbagai bidang juga bagaimana lulusan Perguruan Tinggi mampu berwirausaha dan mempekerjakan orang lain. Proses pembelajaran dan kurikulum yang harusnya mampu mendorong dan mengembangkan kewirausahaan mahasiswa dan dapat dijadikan bekal ketika lulus kelak. Dari beberapa uraian diatas dapat diambil kesimpulan bahwa kewirausahaan adalah kemampuan seseorang dalam menciptakan sesuatu yang baru dan berbeda serta berjiwa berani untuk mengambil berbagai resiko demi memperoleh keuntungan yang lebih besar.

\section{Minat Berwirausaha}

Menurut Slameto (2010:180), minat adalah suatu rasa lebih suka dan ketertarikan pada suatu hal atau aktivitas, tanpa ada yang menyuruh. Sedangkan menurut Djali (2013:121), minat pada dasarnya adalah penerimaan akan suatu hubungan antara diri sendiri dengan sesuatu di luar diri. Sejalan dengan pendapat Slameto, Djali (2013:121) juga menyatakan bahwa : minat dapat diekspresikan melalui pernyataan yang menunjukkan bahwa siswa lebih menyukai suatu hal daripada hal lainnya, dapat pula dimanifestasikan melalui partisipasi dalam suatu aktivitas. Djali juga menyatakan bahwa minat tidak dibawa sejak lahir, melainkan minat akan hadir dan tercipta kemudian, artinya bisa diperoleh ketika sudah melakukan suatu hal atau kegiatan.

Minat berwirausaha muncul karena didahului oleh suatu pengetahuan dan informasi mengenai wirausaha yang kemudian dilanjutkan pada suatu kegiatan berpartisipasi untuk memperoleh pengalaman dimana akhirnya muncul kegiatan untuk melakukan kegiatan tersebut (Yekti Prasetyani, 2008:13). Dari beberapa pendapat para ahli di atas maka dapat disimpulkan bahwa minat merupakan kecenderungan seseorang untuk melakukan sesuatu, yang disebabkan karena rasa suka akan sesuatu, menimbulkan rasa tertarik dan mempengaruhi seseorang untuk berperilaku tertentu. Minat tidak muncul begitu saja tetapi tumbuh dan berkembang sesuai faktor-faktor yang mempengaruhinya.

\section{Jiwa Wirausaha}

Menurut Litunnen (2000), Yonca Gurol \& Nuray Atsan (2006) dalam jurnal penelitian Dedeng Abdul Gani A (2012) jiwa wirausaha merupakan karakteristik personal wirausaha yang didalamnya termasuk psikologi dan karakteristik kognisi yang mempengaruhi perilaku dan alur pikir wirausaha, untuk mengetahui jiwa wirausaha yang dimiliki oleh seseorang tidak terlepas dari pemahaman tentang kewirausahaan dan karakteristik personal wirausahawan. Jiwa kewirausahaan mendorong minat seseorang untuk mendirikan dan mengelola usaha secara maksimal (Kasmir, 2009:15).

Jiwa adalah sesuatu yang abstrak, yang dipelajari hanya pernyataan-pernyataan yang tampak dengan tubuh, atau gejala-gejala yang tampak sebagai gerak-gerik sehingga jiwa merupakan roh, setiap manusia mempunyai sifat dan gejala abstrak terjadi dari perasaan, pikiran, angan-angan dan sebagainya (Hartanti, 2008:24).

Jiwa kewirausahaan yaitu merupakan nyawa kehidupan dalam kewirausahaan yang pada dasarnya merupakan sikap dan perilaku kewirausahaan yang ditunjukkan melalui sifat, karakter dan watak seseorang yang memiliki kemauan dalam mewujudkan gagasan inovatif ke dalam dunia nyata secara kreatif (Hartanti, 2008:25).

Tanggapan penulis bahwa jiwa kewirausahaan dapat merubah pola pikir seseorang untuk berminat menjadi wirausaha. Perlu diperhatikan adanya pengaruh dari dalam diri seseorang itu sendiri untuk minat berwirausaha yaitu tentang jiwa 
kewirausahaannya untuk merasa mampu menjadi seorang wirausaha. Karena jika telah timbul jiwa wirausaha maka tidak akan takut lagi mengambil resiko yang merupakan ciri wirausaha sejati. Jiwa kewirausahaan mampu mengubah mentalitas pencari kerja menjadi mentalitas pencipta lapangan kerja.

Jiwa kewirausahaan dapat mendorong suksesnya seseorang terutama pada era globalisasi dan informasi karena kriteria yang dibutuhkan oleh pasar adalah para lulusan perguruan tinggi yang memiliki jiwa kewirausahaan. Krisis ekonomi menyebabkan jumlah lapangan kerja tidak tumbuh bahkan berkurang karena bangkrut. Hal ini menuntut para lulusan perguruan tinggi tidak hanya mampu berperan sebagai pencari kerja tetapi juga harus mampu berperan sebagai pencipta kerja.

Seorang wirausaha haruslah jiwa seorang yang mampu melihat ke depan. Melihat ke depan bukan melamun kosong, tetapi melihat, berfikir dengan penuh perhitungan, mencari pilihan dari berbagai alternatif masalah dan pemecahannya.

\section{Pemanfaatan Media Sosial}

Perkembangan teknologi informasi di dunia usaha sangat membantu para wirausaha dalam menjalankan usahanya, teknologi informasi memberikan informasi secara akurat, cepat dan tepat sehingga memberikan kemudahan dalam bertransaksi. Hal ini dijadikan kesempatan atau peluang bagi sebagian individu untuk berbisnis.

Salah satu bentuk teknologi informasi yang sedang berkembang saat ini adalah penyebaran, pembelian, penjualan, pemasaran barang dan jasa melalui sistem elektronik seperti internet atau televisi. Menurut Nordiana (2014) dalam jurnal Dewi Masithoh dan Harti (2017) berpendapat bahwa media sosial adalah media yang dikhususkan untuk saling berkomunikasi antar manusia walaupun dengan jarak yang sangat jauh.

Menurut Ardella (2015) media sosial unggul dalam proses penyampaian pesan dimana pesan mampu tersebar secara otomatis, sehingga mempercepat proses persuasi serta mampu menjangkau khalayak yang bersifat heterogen. Sosial media merupakan berbagai aktivitas dua arah dalam berbagai bentuk pertukaran, kolaborasi dan saling berkenalan dalam bentuk tulisan, visual maupun audiovisual (Danis Puntoadi, 2011:2).

Menurut Ardianto dalam Setya Wati (2011:73) mengungkapkan, bahwa media sosial online disebut juga jejaring sosial online bukan media masa online, karena media sosial memiliki kekuatan sosial yang sangat mempengaruhi opini publik yang berkembang di masyarakat.

Pratama (2014:216) juga menyatakan bahwa sosial media lebih mengacu kepada media yang disediakan oleh pencipta atau pengembang aplikasi atau penyedia layanan kepada para pengguna, dengan tujuan untuk memberikan pengguna ruang dan media agar dapat bersosialisasi atau berinteraksi secara online, dengan memanfaatkan jaringan komputer (dalam hal ini internet) berbasiskan OTT (Over The Top) melalui perangkat mobile (smartphone, tablet, handphone, dan komputer biasa atau laptop) atau perangkat terhubung lainnya.

Menurut Hermawan Kartajaya (2008) dalam Hawik Ervina Indoworo (2016) sosial media adalah perpaduan sosiologi dan teknologi yang mengubah monolog (one to many) menjadi dialog (many to many) dan demokrasi informasi yang mengubah orang-orang dari pembaca konten menjadi penerbit konten. Sosial media telah menjadi sangat populer karena memberikan kesempatan orang-orang untuk terhubung di dunia online dalam bentuk hubungan personal, politik dan bisnis.

Sebagai negara yang sedang berkembang, Indonesia selalu mengikuti berbagai perkembangan teknologi informasi hingga akhirnya tiba di suatu masa di mana penggunaan internet mulai menjadi kebutuhan sehari-hari hampir seluruh kegiatan manusia. Dari pengertian diatas dapat disimpulkan bahwa media sosial merupakan suatu kegiatan komunikasi dua arah dalam penyampaian pesan yang dapat tersebar secara otomatis serta tidak terikat oleh jarak dan waktu.

Mudahnya akses internet baik melalui wifi ataupun perangkat gadget memudahkan masyarakat untuk memberikan informasi mengenai suatu produk atau jasa yang dicari. Oleh karena itu, dengan modal yang relatif kecil kegiatan pemanfaatan media sosial merupakan suatu solusi yang dapat digunakan untuk membantu dalam kegiatan jual-beli barang atau jasa melalui penyebaran pesan yang disampaikan kepada khalayak.

Dengan adanya media sosial siapapun dapat dengan mudah menyampaikan informasi mengenai suatu barang atau jasa melalui sistem informasi seperti web atau media elektronik lainnya diharapkan dapat berpengaruh bagi calon wirausaha yang ingin berwirausaha dan hanya memiliki modal yang 
relatif kecil untuk memulai membangun suatu usaha atau bisnis, sehingga kemudahan dalam bertransaksi menggunakan media sosial menjadi faktor penunjang dalam berwirausaha.

\section{Pengembangan Hipotesis}

Dalam melakukan penelitian ini, penulis memerlukan beberapa teori yang telah dikemukakan oleh peneliti terdahulu yang mana oleh penulis dijadikan sebagai bahan analisa dan komparasi pada variabel-variabel yang terkait. Sehingga penulis dapat memperkaya teori yang digunakan dalam mengkaji penelitian yang dilakukan dan tentu saja teori tersebut ditemukan pada kajiankajian penelitian terdahulu. Dari penelitian terdahulu yang penulis jadikan sebagai acuan, penulis tidak menemukan penelitian dengan judul yang sama seperti penelitian yang dilakukan penulis. Namun penulis mengangkat beberapa variabel penelitian dari penelitian terdahulu sebagai referensi dalam memperkaya bahan kajian bagi penulis.

Berikut merupakan penelitian terdahulu yang penulis jadikan sebagai referensi berupa beberapa jurnal penelitian terkait dengan penelitian yang dilakukan penulis.

Penelitian lain yaitu oleh Dewi Masithoh dan Dr. Harti, meneliti Pengaruh Pengetahuan Bisnis dan Pemanfaatan Media Sosial Terhadap Minat Berwirausaha Pada Mahasiswa Fakultas Ekonomi Unesa Angkatan Tahun 2014. Dari penelitiannya di dapat kesimpulan bahwa pemanfaatan media sosial berpengaruh terhadap minat berwirausaha.

Sri Muljaningsih, Soemarno, dkk, melakukan penelitian dengan menggunakan enam variabel yaitu Modal, Tenaga Kerja, Skill, Lahan, Jiwa Wirausaha dan Minat Wirausaha. Sri Muljaningsih, Soemarno, dkk menyimpulkan bahwa secara parsial variabel tenaga kerja, skill, lahan, dan jiwa wirausaha berpengaruh nyata terhadap Minat Berwirausaha.

Pada penelitian yang dilakukan oleh Yudi Siswadi (studi kasus pada mahasiswa jurusan Manajemen Fakultas Ekonomi Universitas Muhammadiyah Sumatera Utara). Penelitian ini berjudul Analisis Faktor Internal, Faktor Eksternal Dan Pembelajaran Kewirausahaan Yang Mempengaruhi Minat Mahasiswa Dalam Berwirausaha. Hasil dari penelitian ini bahwa ada pengaruh yang signifikan dari faktor internal, faktor eksternal dan pembelajaran kewirausahaan terhadap minat berwirausaha.

Penelitian lain oleh Afif Nur Rahmadi dan Budi Heryanto yang meneliti tentang Analisis Faktor-Faktor Yang Mempengaruhi Minat Berwirausaha Pada Mahasiswa Program Studi Manajemen Fakultas Ekonomi Universitas Kadiri. Pada penelitian ini menggunakan variabel Lingkungan Sosial \& Keluarga, Inovasi \& Kreatif, Lingkungan Teknologi, Memiliki Modal dan Minat Berwirausaha. Afif Nur Rahmadi menyimpulkan bahwa faktor yang mempengaruhi Minat Berwirausaha pada mahasiswa Program Studi Manajemen pada Fakultas Ekonomi Universitas Kadiri secara positif dan signifikan yaitu faktor Inovasi \& Kreatif serta Lingkungan Teknologi.

Berdasarkan uraian kerangka pemikiran di atas, maka penulis mencoba mengambil hipotesis dalam pernyataan berikut :

a. Diduga Jiwa Wirausaha memiliki pengaruh terhadap Minat Berwirausaha pada Mahasiswi.

b. Diduga Pemanfaatan Media Sosial memiliki pengaruh terhadap Minat Berwirausaha pada Mahasiswi.

c. Diduga Jiwa Wirausaha dan Pemanfaatan Media Sosial memiliki pengaruh terhadap Minat Berwirausaha pada Mahasiswi.

\section{METODE PENELITIAN}

Jenis metode yang digunakan pada penelitian ini yaitu deskriptif kuantitatif yang mana dalam pengambilan data peneliti menggunakan metode kuesioner yang dibagikan kepada para mahasiswi STIE Dr. Khez. Muttaqien dan STIEB Perdana Mandiri di Purwakarta. Populasi dalam penelitian ini adalah mahasiswi aktif STIE Dr. Khez. Muttaqien dan STIEB Perdana Mandiri dengan jumlah 1594 orang. Berikut tabel jumlah mahasiswi STIE Dr. Khez. Muttaqien dan STIEB Perdana Mandiri di Purwakarta. Dalam menentukan sampel yang digunakan dalam penelitian ini, peneliti menggunakan Teknik Probability Sampling yaitu teknik pengambilan sampel yang memberikan peluang atau kesempatan yang sama bagi setiap unsur atau anggota populasi untuk dipilih menjadi anggota sampel. Sedangkan metode yang digunakan adalah Cluster Sampling atau Area Sampling yaitu teknik pengambilan anggota sampel yang digunakan untuk menentukan sampel bila obyek yang akan diteliti atau sumber data sangat luas. 
Teknik sampling daerah ini sering digunakan melalui dua tahap, yaitu tahap pertama menentukan sampel daerah dan tahap berikutnya menentukan orang-orang yang ada pada daerah itu secara sampling juga. Penetapan jumlah sampel dalam penelitian ini adalah dengan menggunakan rumus Slovin. Berikut hasil perhitungan berdasarkan rumus di atas dari masing-masing strata:

Tabel 2 Jumlah Sampel Pada Masing-masing Strata

\begin{tabular}{|c|c|c|c|}
\hline PTS & Prodi & Populasi & Sampel \\
\hline \multirow{2}{*}{$\begin{array}{l}\text { STIE Dr. } \\
\text { KHEZ. } \\
\text { Muttaqien }\end{array}$} & Akuntansi (S1) & 228 orang & 14 \\
\hline & $\begin{array}{l}\text { Manajemen } \\
\text { (S1) }\end{array}$ & 157 orang & 10 \\
\hline \multirow{3}{*}{$\begin{array}{l}\text { STIEB } \\
\text { Perdana } \\
\text { Mandiri }\end{array}$} & Akuntansi (S1) & 730 orang & 43 \\
\hline & $\begin{array}{c}\text { Manajemen } \\
(\mathrm{S} 1)\end{array}$ & 406 orang & 24 \\
\hline & Akuntansi (D3) & 73 orang & 4 \\
\hline \multicolumn{2}{|c|}{ TOTAL } & $\begin{array}{l}1594 \\
\text { orang }\end{array}$ & 95 \\
\hline
\end{tabular}

Sumber : Data Olahan Peneliti

Dan jika di lihat dari sumber datanya, penulis mengumpulkan data menggunakan sumber primer dan sekunder. Yang mana sumber data primer didapatkan langsung dari mahasiswi dan sumber data sekunder di dapat dari berbagai kajian teori baik jurnal maupun buku serta studi dokumentasi yaitu data-data yang berhubungan dengan objek penelitian.

\section{HASIL DAN PEMBAHASAN}

Dari hasil penelitian dapat diketahui bahwa hasil pernyataan responden tentang variabel $\mathrm{X} 1$ mengenai Jiwa Wirausaha memiliki nilai indeks variabel sebesar 65,37. Hal ini berarti menunjukkan bahwa semua responden memberikan persepsi yang "baik" terhadap variabel Jiwa Wirausaha, tercermin melalui berbagai kegiatan yang mereka ikuti dan adakan dalam rangka menggali potensi diri agar menjadi generasi yang kreatif dan mandiri.

Untuk mengetahui seberapa besar Pemanfaatan Media Sosial digunakan oleh para mahasiswi STIE Dr. Khez. Muttaqien dan STIEB Perdana Mandiri di Purwakarta, peneliti melakukan pengukuran dengan memberikan kuesioner yang terdiri dari 14 butir pernyataan, dimana masing-masing pernyataan memiliki 5 alternatif jawaban yang harus dipilih dan dianggap sesuai dengan pendapat responden. Dari hasil penelitian dapat diketahui bahwa hasil pernyataan responden tentang variabel $\mathrm{X} 2$ mengenai Pemanfaatan Media Sosial memiliki nilai indeks variabel sebesar 66,01. Hal ini menunjukkan bahwa semua responden memberikan persepsi yang "baik" terhadap variabel Pemanfaatan Media Sosial. Media sosial memberikan terobosan untuk merubah pola pikir dilingkungan mahasiswi ekonomi untuk berwirausaha bisa memperkecil resiko untuk gagal dan mempermudah untuk memasarkan produk lebih luas tanpa biaya yang sangat tinggi.

Untuk mengetahui tingkat minat berwirausaha pada mahasiswi STIE Dr. Khez. Muttaqien dan STIEB Perdana Mandiri di Purwakarta, peneliti melakukan pengukuran dengan memberikan kuesioner yang terdiri dari 20 butir pernyataan, dimana masing-masing pernyataan memiliki 5 alternatif jawaban yang dipilih dan dianggap sesuai dengan pendapat responden. Dari hasil penelitian indeks variabel pada variabel Minat Berwirausaha memperoleh nilai sebesar 66,93, angka tersebut menunjukkan bahwa responden memberikan persepsi yang "baik" terhadap variabel minat berwirausaha. Minat berwirausaha dapat tumbuh dan berkembang karena dipengaruhi berbagai faktor eksternal dan internal, salah satunya yaitu jiwa wirausaha dan pemanfaatan media sosial. Validitas data dari masing-masing variabel menunjukkan nilai Rhitung lebih besar dari Rtabel dengan taraf signifikansi 0,05. Begitupun reliabilitas memiliki nilai cronbach alpha yang lebih besar dari 0,60, maka data tersebut dapat dinyatakan valid dan reliabel. Analisis estimasi pernyataan responden terhadap Minat Berwirausaha berada pada persepsi yang baik dengan korelasi yang kuat.

Pengaruh Jiwa Wirausaha terhadap Minat Berwirausaha pada Mahasiswi STIE Dr. Khez. Muttaqien dan STIEB Perdana Mandiri di Purwakarta.

Hasil analisa secara statistik membuktikan bahwa Jiwa Wirausaha berpengaruh positif dan signifikan terhadap Minat Berwirausaha pada Mahasiswi STIE Dr. Khez. Muttaqien dan STIEB Perdana Mandiri di Purwakarta. Dalam penelitian ini membuktikan "Jiwa Wirausaha berpengaruh positif terhadap Minat Berwirausaha" terbukti akan kebenarannya. Atau dengan kata lain, variabel Jiwa Wirausaha berpengaruh secara individual dan signifikan terhadap Minat Berwirausaha pada Mahasiswi. Artinya bahwa Jiwa Wirausaha dapat dijadikan sebagai dasar untuk memprediksi terhadap Minat Berwirausaha pada Mahasiswi STIE Dr. Khez. Muttaqien dan STIEB Perdana 
Mandiri di Purwakarta. Semakin baik nilainilai Jiwa Wirausaha maka semakin tinggi pula tingkat Minat Berwirausaha. Semakin rendah nilai-nilai Jiwa Wirausaha maka semakin rendah pula tingkat Minat Berwirausaha. Hasil penelitian ini sesuai dengan penelitian yang dilakukan oleh Sri Muljaningsih, Soemarno, dkk (2012) yang menunjukkan bahwa Jiwa Wirausaha berpengaruh secara parsial dan nyata terhadap Minat Berwirausaha.

\section{Pengaruh Pemanfaatan Media Sosial terhadap Minat Berwirausaha pada Mahasiswi STIE Dr. Khez. Muttaqien dan STIEB Perdana Mandiri di Purwakarta}

Hasil analisis data secara statistik membuktikan bahwa Pemanfaatan Media Sosial berpengaruh positif dan signifikan terhadap Minat Berwirausaha pada Mahasiswi. Dalam penelitian ini membuktikan "Pemanfaatan Media Sosial berpengaruh terhadap Minat Berwirausaha". Semakin tinggi nilai Pemanfaatan Media Sosial maka semakin tinggi pula tingkat Minat Berwirausaha pada Mahasiswi. Semakin rendah nilai Pemanfaatan Media Sosial maka semakin rendah pula tingkat Minat Berwirausaha pada Mahasiswi. Hasil penelitian ini sesuai dengan penelitian yang dilakukan oleh Dewi Masithoh dan Dr. Harti (2017), yang menunjukkan perubahan teknologi dalam hal ini adalah media sosial dapat mempengaruhi minat untuk berwirusaha, dengan menggabungkan pengetahuan kewirausahaan dan teknologi seperti media sosial, maka akan menjadikan usaha lebih unggul. Karena kita tahu bagaimana memasarkan produk melalui internet, sehingga produk yang dipasarkan akan diketahui oleh masyarakat luas.

\section{Pengaruh Jiwa Wirausaha dan Pemanfaatan Media Sosial terhadap Minat Berwirausaha pada Mahasiswi STIE Dr. Khez. Muttaqien dan STIEB Perdana Mandiri di Purwakarta.}

Dari hasil uji F dapat diketahui bahwa pengaruh secara bersamaan dari Jiwa Wirausaha dan Pemanfaatan Media Sosial terhadap Minat Berwirausaha menunjukkan hasil yang signifikan. Hal tersebut ditunjukkna dari hasil fhitung lebih besar dari F tabel. Sementara itu, tingkat keeratan antara Jiwa Wirausaha dan Pemanfataan Media Sosial terhadap Minat Berwirausaha pada Mahasiswi STIE Dr. Khez. Muttaqien dan
STIEB Perdana Mandiri di Purwakarta menunjukkan nilai koefisien korelasi antara Jiwa Wirausaha (X1) dan Minat Berwirausaha (Y) sebesar 0,752 . Nilai koefisien korelasi diantara interval koefisien 0,60 - 0,799 yang menyatakan tingkat hubungan positif yang "KUAT". Sedangkan koefisien korelasi antara Pemanfaatan Media Sosial (X2) dan Minat Berwirausaha (Y) sebesar 0,821. Nilai koefisien korelasi diantara interval koefisien 0,80 - 1,00 yang menyatakan tingkat hubungan positif yang "Sangat Kuat". Sedangkan hasil perhitungan Koefisien Determinasi (R2), dapat disimpulkan bahwa Jiwa Wirausaha dan Pemanfaatan Media Sosial dalam penelitian ini mampu menerangkan $73,1 \%$ mengenai Minat Berwirausaha pada Mahasiswi STIE Dr. Khez. Muttaqien dan STIEB Perdana Mandiri di Purwakarta. Sisanya dijelaskan oleh variabel lain yang tidak dimasukkan dalam penelitian ini.

\section{KESIMPULAN}

Kesimpulan dari penelitian pengaruh Jiwa Wirausaha dan Pemanfaatan Media Sosial terhadap Minat Berwirausaha pada Mahasiswi adalah sebagai berikut :

a. Terdapat pengaruh yang positif dan nyata antara Jiwa Wirausaha (X1) terhadap Minat Berwirausaha (Y) pada Mahasiswi STIE Dr. Khez. Muttaqien Purwakarta dan STIEB Perdana Mandiri. Artinya semakin tinggi nilai Jiwa Wirausaha maka semakin tinggi pula Minat Berwirausaha pada mahasiswi.

b. Terdapat pengaruh yang positif dan nyata antara Pemanfaatan Media Sosial (X2) terhadap Minat Berwirausaha (Y) pada Mahasiswi STIE Dr. Khez. Muttaqien Purwakarta dan STIEB Perdana Mandiri. Artinya semakin tinggi nilai Pemanfaatan Media Sosial maka akan semakin tinggi pula tingkat Minat Berwirausaha pada mahasiswi.

c. Secara simultan (uji F) menunjukkan bahwa Jiwa Wirausaha (X1) dan Pemanfaatan Media Sosial (X2) menunjukkan ada pengaruh yang positif dan nyata antara Jiwa Wirausaha (X1) dan Pemanfaatan Media Sosial (X2) terhadap Minat Berwirausaha (Y) pada Mahasiswi STIE Dr. Khez. Muttaqien Purwakarta dan STIEB Perdana Mandiri. Artinya semakin tinggi nilai Jiwa Wirausaha dan Pemanfaatan Media Sosial maka akan semakin tinggi pula tingkat Minat Berwirausaha pada mahasiswi. 


\section{REFERENSI}

Anwar, Muhammad. 2014. Pengantar Kewirausahaan Teori Dan Aplikasi. Cet. Pertama. Jakarta : Kencana.

Amrullah, Dedeng Abdul. G. 2013. Tendensi Wirausaha Dan Caracteristik Wirausaha Mahasiswa PTS Di Kabupaten Purwakarta. Jurnal Ekonomi Dan Bisnis Program Studi Manajemen STIE Dr. Khez. Muttaqien Purwakarta. ISSN 2252-4495pp.50-60. Edisi 3 No. 1.

Ardella, A. M. P. (2015) Pemanfaatan Media Sosial Oleh Senyum Community Sebagai Persuasi Cyber Social Enterprise. Journal UMS.

Daryanto. 2012. Pendidikan Kewirausahaan. Yogyakarta : Gava Media.

Ghozali, Imam. 2005. Aplikasi Analisis Multivariate Dengan Program SPSS. Semarang : Universitas Diponegoro.

H. Djaali. 2013. Psikologi Pendidikan. Jakarta : PT Bumi Aksara.

Hartanti. 2008. Manajemen Pengembangan Kewirausahaan (Entrepreneurship) Siswa SMK 4 Yogyakarta. Tesis Magister Universitas Negeri Yogyakarta.

Hendro, M.M 2011. Dasar-Dasar Kewirausahaan : Panduan Bagi Mahasiswa Untuk Mengenal, Memahami, Dan Memasuki Dunia Bisnis. Jakarta : Erlangga.

Indoworo, Hawik. E. 2016. Menumbuhkan Jiwa Wirausaha Melalui Peran Sosial Media. Jurnal Informatika UPGRIS. Vol 2 No. 1 (2016).

Kasmir. 2008. Kewirausahaan. Jakarta : PT. Raja Grafindo Persada.

Koranti, Kosmi. 2013. Analisa Pengaruh Faktor Eksternal Dan Internal Terhadap Minat Berwirausaha. Jurnal Psikologi Ekonomi, Sastra, Arsitektur dan Teknik Sipil Bandung. ISSN 1858-2559 Vol. 5.

Masithoh, Dewi dan Dr. Harti. 2017. Pengaruh Pengetahuan Bisnis Dan Pemanfaatan Media Sosial Terhadap Minat Berwirausaha Pada Mahasiswa Fakultas Ekonomi Unesa Angkatan Tahun 2014. Jurnal PTN UNESA. ISSN 2337-6708 Vol. 01 No. 02

Muljaningsih, Sri, dkk. 2012. Faktor-Faktor Yang Mempengaruhi Minat Wirausaha Pengolahan Pangan Organik Pada Perempuan Tani Di Desa Wonokerto, Bantur, Malang. Jurnal Universitas Brawijaya. ISSN 1411-0199. Vol. 15 No.2.
Nasution, A.H., dkk. 2007. Entrepreneurship Membangun Spirit Teknopreneurship. Yogyakarta : Andi Offset.

Prasetyani, Yekti. 2008. Pengaruh Kreativitas Kemandirian Siswa Dan Lingkungan Tempat Tinggal Terhadap Minat Berwirausaha Siswa Kelas XI Program Keahlian Akuntansi SMK Muhammadiyah 2 Wonogiri. Laporan Penelitian UNY.

Pratama, I Putu Agus. E. 2014. Handbook Jaringan Komputer. Bandung : Informatika.

Puntoadi, Danis. 2011. Menciptakan Penjualan Melalui Sosial Media. Jakarta : PT Elex Media Komputindo.

Purwanti, Yatmi. 2008. Meningkatkan Minat Dan Prestasi Belajar IPS Sejarah Melalui Penerapan Pendekatan Pembelajaran Make A Match Pada Siswa SMP Negeri 4 Gamping, Sleman, $Y K$. Yogyakarta : FISC UNY.

Rahmadi, Afif Nur dan Budi Heryanto. 2016. Analisa Faktor-Faktor Yang Mempengaruhi Minat Berwirausaha Pada Mahasiswa Program Studi Manajemen Fakultas Ekonomi Universitas Kadiri. Jurnal Manajemen Fakultas Ekonomi Universitas Kadiri. ISSN 153-169. Vol. 1 No. 2

Riduwan, M.B.A dan Engkos Achmad K, SE., MM. 2013. Path Analysis. Cet. Kelima. Bandung : Alfabeta Bandung.

Setya Wati, Errika Dwi. 2011. Komunikasi dan Media Sosial. Semarang : Universitas Semarang.

Siswadi, Yudi. 2013. Analisis Faktor Internal, Faktor Eksternal Dan Pembelajaran Kewirausahaan Yang Mempengaruhi Minat Mahasiswa Dalam Berwirausaha. Jurnal Manajemen \& Bisnis. ISSN 16937619. Vol. 13 No. 01

Slameto. 2010. Belajar dan Faktor-faktor yang Mempengaruhinya. Jakarta : Rineka Cipta.

Sugiyono. 2010. Metode Penelitian Kuantitatif Kualitatif dan $R \quad \& \quad D$. Bandung : Alfabeta

Suryana. 2006. Kewirausahaan. Edisi 3. Jakarta : Salemba Empat. 